\title{
Az RDC III dozimetriai rendszer alkalmazhatóságának vizsgálata, 20 évvel a modernizálása után

\section{AZ EREDETI RDC III RENDSZER}

\section{AZ ESZKÖZ ÖSSZETÉTELE}

A Magyar Honvédségben 1986-tól rendszeresített - NDK gyártmányú - RDC III harcászati személyi dozimetriai rendszer az alábbi 4 elemből állt:

1. $R D C$ III $D$ termolumineszcens gamma-neutron dózismérő1.

2.RDC III A kiértékelő készülék, amelynek feladata a dózismérők „kifűtése” és a mérési eredmények megjelenítése.

3. RDC III N hálózati tápegység biztosítja a kiértékelő készülék számára a megfelelő tápfeszültséget. A hazai rendszeresítést követően készült egy magyar (MIKI) fejlesztésű tápegység is, amelyet nem a kiolvasó alá, hanem a berendezés hátoldalára lehet felszerelni. Ez az RDC III NM megjelölést kapta.

4. Beszabályozó készlet, amely segítségével a kiértékelő készülék egyes elektronikus paraméterei (pl. erősítés) beállítására nyílt lehetőség.

A csernobili atomerőmű katasztrófáját követően a honvédségi dozimetriai rendszereknek is alapvető funkcionális változáson kellett átesniük. Ennek lényege abban ált, hogy amíg azt megelőzően a háborús normatívákra - pontosabban az atomfegyverek lehetséges alkalmazásával vívott küzdelemből fakadó feladatokra - kellett felkészülni, ezt követően a természetes háttérzsugázási szintek, illetve az ettől szignifikánsan eltérő dózis- és dózisteljesítmény értékek mérése is szükségessé vált.

A változások tükrében a kiértékelő készülék a rendszeresítést követő évtizedben teljesen elavulttá vált. Ennek egyik legfőbb oka, hogy a 3R-es ( $\approx 30 \mathrm{mGy})$ alsó méréshatár legalább egy nagyságrenddel nagyobb a kívánatosnál. A másik alapvető problémát az eszköz kalibrációs rendszerének elavultsága jelentette. A beépített ellenőrző fényforrásában lévő trícium olyan mértékben lefeleződött, amelyet a berendezés mechanikus korrekció tárcsájával 1994-től (!) kezdve már nem lehetett tovább szabályozni. Ebből következett, hogy - az egyébként még müködőképes elektronikával rendelkező - berendezések helytelen alapértékekkel számoltak a pontatlan kalibráció miatt. Tehát a dózismérők kifüthetők voltak ugyan, azonban a mérési eredményként a kijelzőn megjelenő értékek rendre kívül estek a megengedett hibahatárokon.

További hiányosságként jelentkezett, hogy az eszköz nem támogatta semmilyen adatfeldolgozó rendszer használatát, valamint a mérési eredményeket nem Gray, hanem röntgen mértékegységben jelezte ki.

A probléma megoldására a MH Vegyivédelmi Főnökségének igénybejelentése alapján, 1993-ban a Haditechnikai Intézetben kutatás-fejlesztési tevékenység indult. Az eredeti igénybejelentés egy teljesen új személyi dozimetriai rendszer kialakítását célozta, azonban a többszöri egyeztetések után - figyelembe véve a Tudományos-múszaki Tanács javaslatát -, az illetékesek a régi rendszer felújítása

\section{1. ábra. Az RDC III D doziméter}

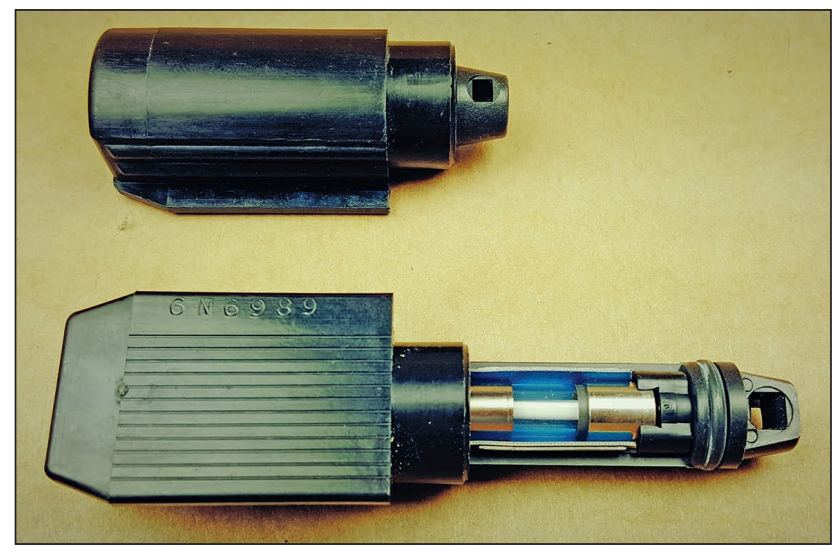

ÖSSZEFOGLALÁS: A Magyar Honvédségben 1986-ban rendszeresíttették a Német Demokratikus Köztársaságban gyártott RDC III harcászati személyi dozimetriai rendszert. A kiértékelő készülékek („kiolvasó”), illetve azok szolgáltatásainak elavulása miatt tíz évvel később modernizálásuk szükségessé vált. Az átalakított eszközrendszert 1998-ban, valamint a tovább modernizált kiolvasót 2001ben rendszeresítették. A tanulmány beszámol az eszközök megváltozott alkalmazhatóságáról az eltelt idő alatt. A tanulmány szerzóje a legfrissebb méréseket a centenáriumát ünneplő Gamma Műszaki Zrt. laboratóriumában végezte el.

KULCSSZAVAK: személyi dozimetria, termolumineszcens doziméter (TLD), Gamma Zrt., kutatás-fejlesztés (K+F), modernizáció
ABSTRACT: The RDC III tactical personnel dosimetry system manufactured in the former German Democratic Republic was taken into service in the Hungarian Armed Forces in 1986. The obsolescence of evaluation devices ("readers") and their services necessitated their modernization ten years later. The modernized system was taken into service in 1998 and the further modernized reader in 2001. This article reports on how the applicability of the tools has changed since then. The author of the study performed the latest measurements at the laboratoy of Gamma Müszaki Zrt., celebrating its centenary. KEY WORDS: personal dosimetry, thermoluminescent dosimeter (TLD), Gamma Technical Corporation, Research and development (R\&D), modernisation

\footnotetext{
Nyá. ezredes. Korábban a HTI kutatásért és fejlesztésért felelős intézetvezető-helyettese. ORCID: 0000-0001-9598-1187
} 


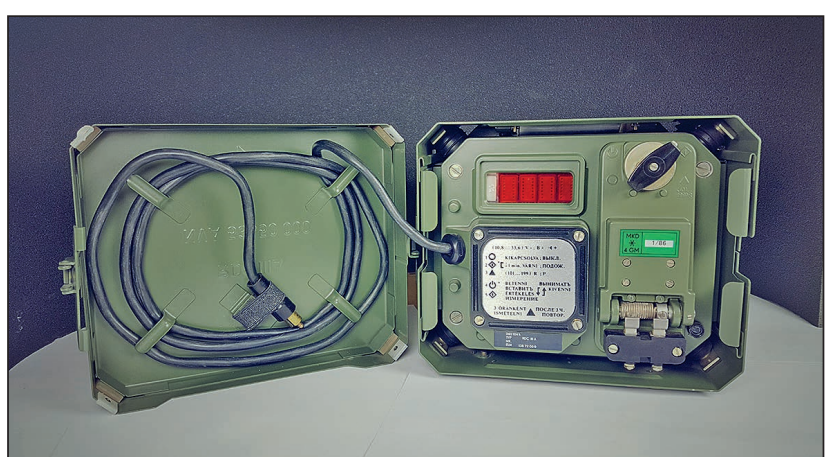

2. ábra. Az RDC III A kiértékelö készülék

mellett döntöttek. Egyértelműen a korszerűsítés mellett szólt, hogy annak költségei nagyságrendekkel kisebbek, mint egy teljesen új rendszer kialakításáé, valamint az, hogy kedvező eredménnyel zárultak az előzetesen végrehajtott felhasználhatósági vizsgálatok. Az egykori Haditechnikai Intézet munkatársaként én irányítottam a Magyar Honvédség személyi dozimetriai rendszerének modernizálását, így annak folyamatáról személyes tapasztalataim alapján tudok beszámolni.

\section{FELHASZNÁLHATÓSÁGI VIZSGÁLATOK}

A fejlesztési tevékenység első (kísérleti-kutatási) fázisában végrehajtottuk az RDC III készlet teljes körű felhasználhatósági vizsgálatait, amelyek részben a KFKI Atomenergia Kutató Intézetében, részben pedig a Gamma Müszaki Rt.-nél folytak. Ezekre az eredménye alapozva készülhetett el a későbbiekben a kiértékelő berendezés kísérleti mintapéldánya.

A felhasználhatósági vizsgálatok - az előzetes várakozásoknak megfelelően - pozitív eredménnyel zárultak. A vizsgálati jelentések végkövetkeztetései:

- Az RDC III D dózismérők eredeti állapotukban is megfeleltek a megváltozott körülményeknek. Rendszerben tartásuk nem igényelt sem változtatást, sem felújítást. A kísérletek egyértelműen igazolták, hogy egy érzékenyebb fényérzékelő elem és egy pontosabb kifütési algoritmus alkalmazásával a dózismérők lehetőséget biztosítanak az alsó méréshatár minimum egy nagyságrenddel történő csökkentésére. A költségek optimalizálásának szempontjából meghatározó jelentőségű, hogy akkoriban több százezer darab ilyen dózismérő volt a Magyar Honvédségnél. (Információim szerint az akkori határőrségnél, polgári védelemnél szintén rendszeresítve volt az RDC III készlet.)

- Lényeges megjegyezni, hogy - az időközben elvégzett vizsgálatok igazolták, hogy - az RDC III $D$ dózismérők neutron-érzékenysége elhanyagolható, így a továbbiakban az RDC rendszert gamma-dózismérőnek kell tekinteni.

- A beszabályozó készlet, a kezelési utasításának átdolgozása után továbbra is alkalmazható, rendszerben tartható.

- Az RDC III A kiértékelő egység konstrukciós kialakítása megfelelő, mechanikája megbízhatónak bizonyult. $A$ vizsgált készülékek rendeltetésszerűen működtek, kivéve, hogy a kalibráló fényforrás lebomlása miatt már nem voltak hitelesíthetők. (Az ebből származó hiba átlaga: - 17\%.) A konstrukció megfelelő alapot biztosított egy korszerűsített eszköz megépítéséhez.

A felújított eszköz, az RDC III AG, az eredeti $R D C$ III $A$ készülék mechanikai egységeinek és ellenőrző fényforrásá-

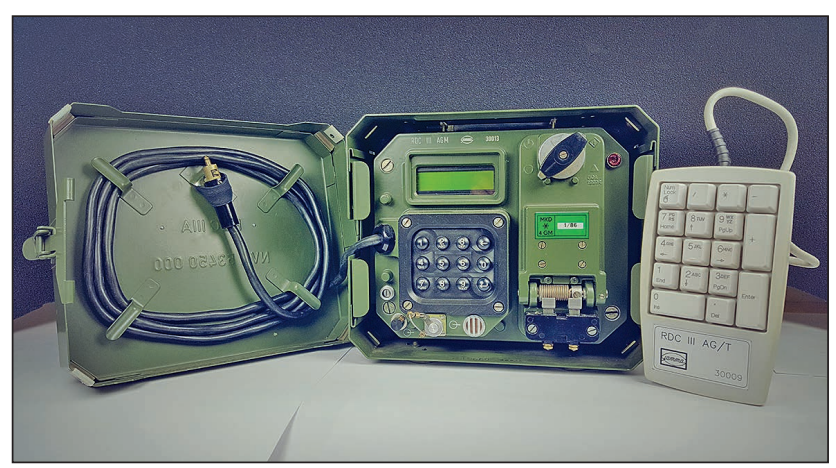

3. ábra. Az RDC III AGM készülék, jobb oldalon a külső klaviatúra

nak felhasználásával került kialakításra, teljesen új elektronika és érzékenyebb fényérzékelő elem (fotoelektronsokszorozó) beépítésével. A Gamma Műszaki Részvénytársaság bázisán elkészült három mintapéldány üzemi és haditechnikai ellenőrző vizsgálatai, valamint a csapatpróba alapján megállapíthattuk, hogy az eredeti normatív paraméterek megtartása mellett a kalibrálhatóság kérdése évtizedekre megoldódik. Ezzel együtt a mérési tartomány alsó határa közel két nagyságrenddel csökkenthető, a számítógépes kapcsolat pedig lehetőséget teremt a korszerü adatfeldolgozásra.

Az alkalmazásba vétel szempontjából kedvező volt, hogy a műszer átalakítása az eredeti készletre vonatkozó előírásokat alapvetően nem változtatta meg. Ez alól (szervezési szempontból) jelentős kivételt csak az jelentett, hogy a 3 hónapnál hosszabb ideig tárolt dózismérőket kiosztás előtt ki kellett füteni. Az eredetileg 6 hónapra deklarált intervallum felére csökkentését az eszköz érzékenyebbé válása indokolta.

Az ellenőrző vizsgálatok folyamán egy újabb szempont is felmerült: az adatfeldolgozás érdekében szükséges a doziméterek egyedi azonosítójának begépelése a kiolvasóba. A fejlesztés során tapasztaltuk, hogy a doziméterek között - az előzetesen felmért mennyiséghez képest - sokkal jelentősebb számban voltak olyanok is, amelyeknek azonosítója nemcsak kizárólag számokat, hanem betűket is tartalmazott. Az eredeti tervek szerint a kizárólag számokat tartalmazó azonosítóval rendelkező doziméterek feleltek volna meg a Magyar Honvédség igényeinek. Az előzetes becslések nem igazolódtak. Emiatt szükségessé vált a kiértékelő előlapjára szerelt, illetve a külső klaviatúra, valamint a fogadó elektronika alkalmassá tétele ezeknek a karaktereknek a kezelésére is.

Ezt a feladatot 2001-re sikerült eredményesen befejezni. Az így kialakított, tovább modernizált eszköz lett az RDC III AGM.

\section{AZ ÁTALAKÍTOTT, MODERNIZÁLT KÉSZZ̈LÉK MEGVÁLTOZOTT PARAMÉTEREI, VALAMINT ÚJ SZOLGÁLTATÁSAI}

A rendszer alsó mérési, illetve kijelzési tartománya közel két nagyságrenddel lett alacsonyabb az eredetinél. ( $\mathrm{Az}$ eredeti készülék törzskönyve szerint $3 R(\approx 30 \mathrm{mGy})$ volt az alsó méréshatár.) Az új tulajdonságok:

1. Az RDC III AGM készülék mérési tartománya $400 \mu \mathrm{Gy}-$ 10 Gy, kijelzési tartománya pedig 100 MGy-400 Gy, illetve 10 Gy-100 Gy.

2. Az eszköz „lelke” egy mikroprocesszor, amelynek feladata a lehetséges folyamatok (kalibráció, törlés, mérés, adatgyűjtés és tárolás) vezérlése. 
3. A készülék lehetővé teszi az adatok megjelenítését. A beépített memória képes legalább $32000 \mathrm{db}$ adatcsomag (adatcsomag = mérési eredmény + a dózismérő egyedi azonosítója + a mérés időpontja) átmeneti tárolására (kiolvasásig, illetve törlésig), valamint azok számítógépes mérés-adatgyűjtő rendszerbe történő továbbítására.

4. A kalibráló egység átalakítása során a mechanikus korrekciótárcsa kiszerelésre került, szerepét nagyságrendekkel pontosabb elektronikus mechanizmus vette át. A vizsgálatok során elvégzett méréssorozattal meghatározható volt a „tríciumlámpa” fényintenzitásának csökkenési üteme, így a kapott eredmények felhasználásával egy kellően pontos korrekciós függvényt tudtunk meghatározni. A kalibrációt ennek a függvénynek a segítségével a mikroprocesszor napi korrekcióval automatikusan képes elvégezni. (Az eredeti készüléken évente kellett manuálisan átállítani a „korrekciótárcsát".)

5. A készülékbe egy olyan óra IC került, amely saját tápforrással rendelkezik, így a berendezés kikapcsolt állapotában is legalább tíz évig működik folyamatosan. Az óra adatai az adatképzés, illetve a kalibráció során elengedhetetlenül szükségesek.

6. A doziméterek által kibocsátott fénymennyiség érzékelését a korábban beépített fotódióda helyett, egy több nagyságrenddel érzékenyebb fotóelektron-sokszorozó (photomultiplier - PMP) végzi.

7. Az előlapra egy 12 gombos klaviatúra került, amelynek funkciója - bekapcsolást követően - a mérés/törlés funkció beállítása, a doziméterek azonosítójának, illetve szükség esetén a törlőkód beírása, továbbá a kijelző fényerősségének beállítása. A gombok segítségével lehetővé vált a kijelző fényerősségének beálítása is. Szintén az előlapra került a számítógépes kapcsolat, az opcionális alfanumerikus klaviatúra számára létesített csatlakozó, valamint az akusztikus riasztáshoz szükséges zümmer. A készülék új, 2×16 karakteres kijelzője folyadékkristályos, alfanumerikus és üzem közben folyamatos háttérvilágítással rendelkezik. Külsejét tekintve, a berendezés egyebekben nem tér el az eredetitől.

8. Az eszköz rendelkezik önellenőrzési funkcióval, hiba esetén a kiolvasást letiltja, riasztó jelzést ad, és megjeleníti a hiba típusát. A kijelző lehetővé teszi a mérési eredmények, az eszköz állapotának, valamint a hibaüzenetek megjelenítését, valamint a bevitt adatok (dózismérők gyári számai) ellenőrizhetőségét és javíthatóságát.

9. A számítógépes kapcsolat a „beálító program" segítségével lehetővé tette az eszköz órájának és törlő kódjának állíthatóságát. A fejlesztés során „technológiai szoftverek” is készültek, amelyek a készülék belső szoftvereinek módosíthatóságát, valamint a működéshez szükséges egyéb paraméterek megváltoztathatóságát szolgálják.

10. Az eszköz - alapbeállításából adódóan hangjelzést ad $D \geq 0,5$ Gy esetén, belső szoftvere lehetővé teszi, hogy a „beállító program” segítségével a küszöbértéket később tetszőlegesen lehessen változtathatni, illetve több küszöbérték megadását is.
11. A készülék „törlés üzemmód” beállítására is alkalmas. Ezáltal jelentős időmegtakarítás érhető el abban az esetben, ha a dózismérők raktárból kerülnek kiosztásra. Ebben az esetben ugyanis nincs szükség a dózismérők kiértékelésére, csupán a raktározás során öszszegyűjtött - hasznos információt nem hordozó - dózisok kifütésére. A kifütési-törlési folyamat jelentősen (kb. 60\%-al) kevesebb időt vesz igénybe, mint a lényegesen bonyolultabb algoritmusú kiértékelés. A hasznos információk védelme érdekében a törlési üzemmódot csak hat számjegyből álló kóddal lehet beállítani, szintén a „beálító program” segítségével.

12. A csapatpróba tapasztalatai nyomán került az eszközkészletébe egy opcionális külső alfanumerikus klaviatúra (a készülék mellett jobb oldalon látható a 3. ábrán), amely a nem tábori körülmények közötti alkalmazás esetén biztosítja a készülék lényegesen könynyebb kezelhetőségét. Ennek funkciói teljesen megegyeznek az előlapon elhelyezett tasztatúráéval.

\section{Az RDC III AGM KÉSZÜLÉK MÜKÖDÉSI ELVÉNEK LEIRÁSA}

A működés folyamatának blokkvázlatát a 4. ábra szemlélteti.

\section{4. ábra. Az RDC III AGM készülék blokkvázlata}

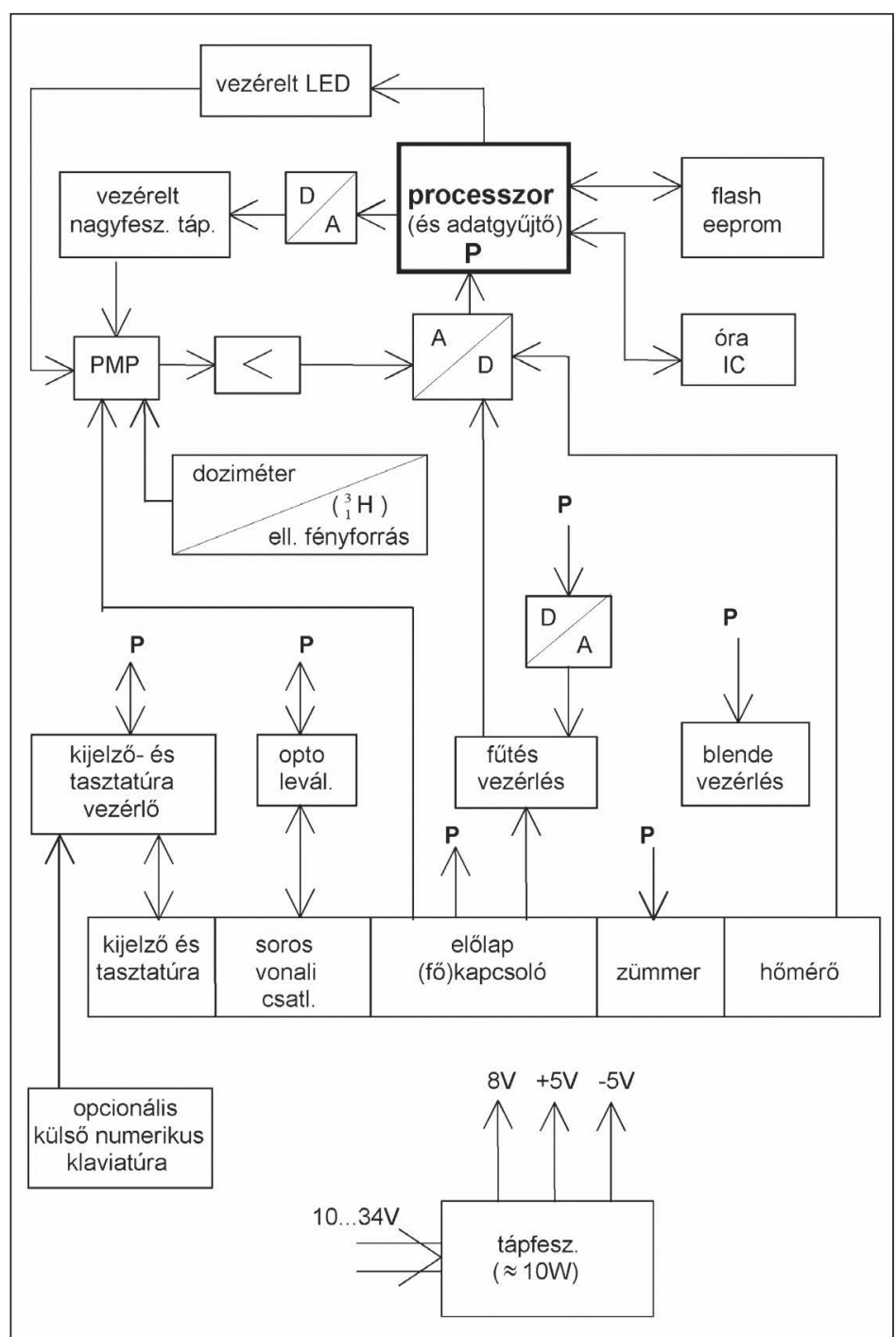


A mérési folyamat: $\mathrm{Az}$ öt nagyságrend átfogású dózismérés alapja a kifütés során világító doziméter fényáramának pontos mérése, és a kifütési görbe egyformaságának biztosítása.

Az eltérő ellenállású doziméterek fűtőteljesítményét a kiértékelés alatt a mikroprocesszor vezérlésű, kapcsolóüzemű fűtőáramkör szabályozza a beállított fütési algoritmusnak megfelelően. A doziméterre jutó teljesítményt a fütőfeszültség és a fütőáram mérésével, a kitöltési tényező változtatásával szabályozza a készülék.

A doziméter fényét fotóelektron-sokszorozó (PMP) érzékeli és átkapcsolható erősítésű áramkör illeszti az A/D konverterre, illetve a mikroprocesszoros kiértékelő egységre. A fénymérés négy méréstartományban működik, az egyes méréshatárok közötti szorzó kb. 32-szeres. A méréshatár váltása a fotóelektron-sokszorozó nagyfeszültségének, illetve az illesztő áramkör erősítésének változtatásával történik.

A pontos mérést a fényárammérés kalibrálása biztosítja. Bekapcsolás után „Kalibrálás” állásban a beépített tríciumos ellenőrző fényforrásnak a radioaktív bomlással korrigált értéke alapján a műszer beszabályozza a harmadik méréshatárhoz tartozó erősítést. „Mérés” állásba kapcsolva a blende záródik, és a beépített vezérelhető áramú LED segítségével a többi méréshatárt a fotóelektron-sokszorozó nagyfeszültségének változtatásával, a processzoros vezérlő áramkör egymáshoz szabályozza.

A továbbiakban minden mérés előtt - a LED fényét változtatva minden méréshatárban - a rendszer ellenőrzi a fényerősítést. Ha az eltérés 7\%-nál nagyobb, ismételt kalibrálást kér.

A készülék egy mérési ciklus alatt az alábbi műveleteket hajtja végre:

1. Méréshatárok ellenőrzése:

2. Háttér fényáram-mérés:

3. Blendenyitás:

4. I. fütés - a fő csúcs kifütése:

5. I. hőntartás - a folyamat végén melegháttér-mérés: $5 \mathrm{~s}$

6. II. fütés - a maradék háttér csökkentésére: 5-10 s (ennek hosszúsága a mért dózistól függően változik)

7. II. hőntartás

$5 \mathrm{~s}$

A fenti felsorolásban az egyes fázisok mellett, azok végrehajtásának időtartama szerepel. A fütési időket és a kiértékelés időtartományának határait a belső hőmérséklet függvényében a készülék automatikusan módosítja. A dózis kiszámítása a kiértékelési tartományban 0,1 másodpercenként mért fényáram összegzésével történik.

A mérési eredmények, állapotjelzések, hibaüzenetek stb. megjelenítésére $2 \times 16$ karakteres alfanumerikus kijelző szolgál. A beépített zümmer az üzenetek megjelenését hangjelzéssel kíséri. A doziméterek sorszámának bevitelére tasztatúra szolgál. A beépített elemes óraáramkör segítségével megjeleníthető a pontos dátum és idő.

A mért eredményeket a mérés időpontjával és a doziméter sorszámával együtt a berendezés eltárolja, törlés nélkül több mint 32000 mérési eredmény gyűjthető.

A törlési folyamat: A doziméterek tárolást követő használatba adásakor a tárolás során gyűjtött dózist törölni szükséges, törlés üzemmód használatával. Ebben az üzemmódban a fütés a következő szakaszra osztható (jelezve az egyes fázisok végrehajtásának időtartamát):

1. fütés

2. hőntartás

$\sim 18,5 \mathrm{~s}$

A fejlesztés során - a műszer belső szoftverén, a technológiai szoftvereken” és a "beállító programon” kívül - két további szoftver is készült, amelyek az adatkezelést szolgálják. Az egyik az adatkiolvasó, amelynek feladata az eszközben tárolt információk számítógépbe történő átmásolása. A másik szoftver az adatkezelés egy lehetséges módját va-

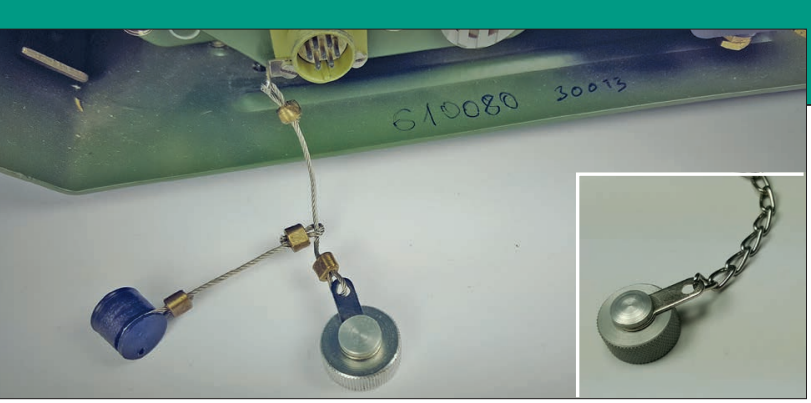

5. ábra. A tesztelés során az eszköz számítógépes csatlakozójának porvédő sapkája leszakadt, attól kezdve a gyártó cég lánc helyett acélsodronnyal rögzíti a múszerek porvédő sapkáit. Az ábrán az RDC III AG készülék számítógépes csatlakozójának porvédője láncos rögzítéssel a jobb oldalon, illetve acélsodronyos rögzítéssel a bal oldalon

lósítja meg. Az aktuális adatok (katonai szervezetek megnevezése, illetve azok állományába tartozó személyek tajszámai és doziméterük gyári száma) előzetes bevitele és a kiértékelő készülékből letöltött adatok összerendelése alapján személyekre, illetve alakulatokra vonatkozó különféle összegzések készíthetők. Ezek a programok könnyen telepíthetők, és - az ezredforduló környékén korszerűnek számító - Microsoft Windows 3.1 vagy Windows for Workgroups 3.11 változatai alatt egyszerűen használhatók.

$\mathrm{Az}$ eszközhöz rendszeresített beszabályozókészlet a fentiekben leírt önkalibráló mechanizmus miatt, eredeti jelentőségét elvesztette. A korszerűsítés során a készülék kezelési utasítását is átdolgoztuk és egy „korrekciós szoftver” is készült hozzá, amely a készletben lévő „trícium lámpák" töltetének bomláskövetését szolgálja. Ezek segítségével a készletet szükség esetén a berendezés ellenőrzésére lehet alkalmazni.

\section{Összegzés}

Összességében megállapítható, hogy a végrehajtott átalakításoknak (elsősorban a fotóelektron-sokszorozó, az új kalibráló rendszer és a mikroprocesszoros vezérlésű kiolvasás) köszönhetően az érzékenységen kívül, a rendszer pontossága is javult.

Az 1995-2001 között elvégzett kutatás-fejlesztési tevékenység, valamint a csapatpróbát követő visszajavítások, módosítások végrehajtásával egy olyan korszerủ eszköz állt rendelkezésre, amely műszaki paraméterei, szolgáltatásai alapján hosszú ideig képes feladata ellátására. Az elvégzett felújítási munka egyik nagy előnye volt, hogy általa az eszköz változtatás nélkül illeszkedett a vegyivédelmi csapatok, illetve az egészségügy általános eszközrendszerébe, tág lehetőségeket nyújtva a Magyar Honvédség személyi dozimetriai nyilvántartó-rendszerének további korszerűsítésére.

(Folytatjuk)

\section{FELHASZNÁLT IRODALOM}

[1] Nagy Lajos György: Magkémiai és izotóptechnikai gyakorlatok (kézirat), Budapest, Tankönyvkiadó, 1973;

[2] Műszaki leírás, kezelési-, karbantartási- és tárolási utasítás.

\section{JeGYZETEK}

1 A termolumineszcens anyag (esetünkben $\mathrm{CaF}_{2}: \mathrm{Mn}$ ) az ionizáló sugárzás energiájának egy részét tárolni képes. Kiértékeléskor/ kiolvasáskor melegítés hatására (esetünkben $\approx 350^{\circ} \mathrm{C}$ ) felszabadul a tárolt energia, amelynek jelentős hányada látható fény formájában jelentkezik. A „kifütés” során kibocsátott fény mennyiségének mérése alapján a termolumineszcens anyag által elnyelt dózis kiszámítható. 